\title{
大山テフラの岩石記載的特徵と大山最下部 テフラ層中のテフラの対比
}

\author{
加藤 茂 弘*1 $・$ 山下 透*2 $・$ 檀原 徹*2
}

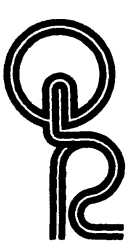

大山テフラ層中の大山奥津軽石 (DOP), hpm1 軽石, hpm2 軽石, 大山別所軽石 (DBP), 大山 蒜山原軽石, 下のホーキ，オドリ火山砂，上のホーキ，弥山軽石の 9 層のテフラについて, 火山 ガラスや重鉱物の屈折率など詳細な岩石記載的特徴を明らかにした。これらのテフラはすべて類 似した特徵を有するが，カミングトン閃石や褐色普通角閃石の含有量，火山ガラス・普通角閃 石・カミングトン閃石の屈折率に違いがあり，これらを指標に同定・対比できる．これらのテフ ラの中で, DOP と hpm1 軽石は一致した岩石記載的特徴を持つことから，相互に対比が可能で あり，さらに DBP は少なくとあ近畿地方北部にまで分布する可能性がある.

キーワード : 大山テフラ層, 岩石記載的特徵, 屈折率, 大山奥津軽石, hpm1 軽石, 大山別所軽石, 対比

\section{I. は じめに}

大阪湾周辺に分布する大阪層群や段丘構成層，および 平野地下に伏在する中・上部更新統には, 角閃石を主と して斜方輝石を伴い, 微量の黒雲母を含むという重鉱物 組成のテフラが挾まれている(図 1)，それらは，大阪層 群中の Ma8 層に挾まれるカスリ火山灰 (吉川, 1976), 大阪平野地下の Ma11 (2) 層に挾まれる甲子園浜 III VI 火山灰 (吉川ほ加, 1993), 姶良 Tn 火山灰 (AT : 町田・ 新井，1976）の上位に挾まれる鬼虎川火山灰（吉川ほか， 1986）などである. 福知山盆地の中部更新統・福知山層 (福間・藤田, 1986)に挾まれる物部火山灰 (小滝ほか, 2002) や, 琵琶湖湖底堆積物中の BT $44 \sim B T 49$ 火山灰群 （吉川・井内，1991）も, これらと類似した岩石記載的特 徵を有する.

近畿地方中・北部に分布するこれらのテフラは，その 重鉱物組成から，中国地方の大山火山を給源とする可能 性が指摘されてきた（町田ほか，1991; 吉川・井内, 1993 など). 大山火山近傍に分布するテフラは，大山最 下部・下部・中部・上部の 4 つのテフラ層に区分されて
おり (山陰第四紀研究グループ，1969), 各層中のテフラ の層序や岩相，重鉱物組成，強磁性鉱物の熱磁化特性が 明らかにされてきた (岡田ほか, 1990 など). 大山生竹軽 石 (DNP), 大山関金軽石 (DSP), 大山倉吉軽石 (DKP) （いずれす町田・新井, 1979）については, 斜方輝石・普 通角閃石・カミングトン閃石の屈折率や晶形の特徵など が明らかにされた (町田・新井, 1979 ; 古澤・梅田, 2002 a). さらに古澤・梅田 (2002 b) は, 大山最下部テフ ラ層で 10 層, 大山下部テフラ層で 3 層の合計 13 層のテ フラの詳細な岩石記載的特徴を記載し, これらのいく か力琵琶湖湖底堆積物中の BT 44 BT 49 火山灰群と対 比できる可能性を示した. しかし，大山火山近傍で $1 \mathrm{~m}$ をこえる厚さを有し，かつ粗粒の軽石から構成される大 山奥津軽石 (DOP) や大山別所軽石 (DBP) (と屯に岡田, 1996)，およびAT の上位に累重する大山上部テフラ層 中の諸テフラについては, 詳細な岩石記載的特徴は検討 されていない.

本研究では, DOP と DBP が模式的に分布する岡山県 分架村祘山傆下福田の露頭 (図 1) において, 大山最下 部・下部テフラ層中の 5 層のテフラと, 大山上部テフラ

2004 年 2 月 12 日受付. 2004 年 7 月 17 日受理.

${ }^{*} 1$ 兵庫県立人之自然の博物館 テ669-1546 三田市弥生が丘 6丁目. E-mail

*2 株式会社京都フィッション・トラック $\mathbf{T} 603-8832$ 京都市北区大宮南田尻町 44-4. 


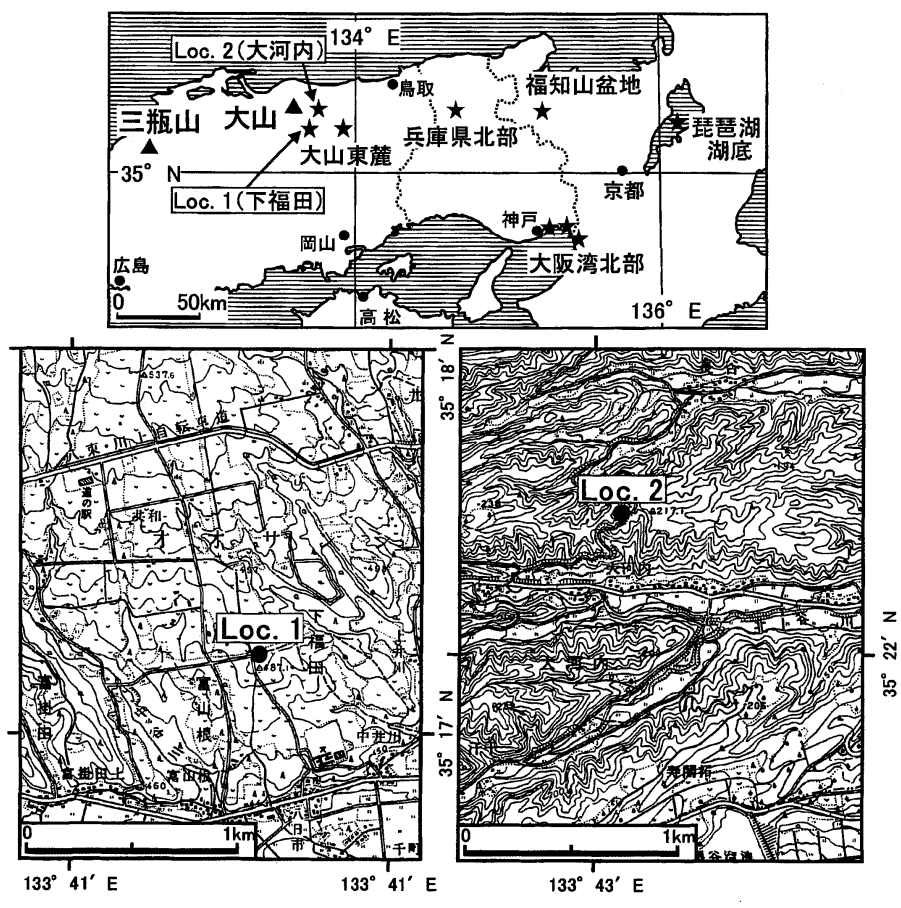

図 1 調査地点抢よび大山東麓から近畿地方北部における大山火山起源と 推定された中期更新世テフラの分布地域

Locs. 1，2 は分析したテフラ試料の採取地点. 星印は大山火山起源と推定されたテフラの扔むな分布地域で，大山 東麓は岡田 (1996), 兵庫県北部は加藤ほか (2001), 福知山盆地は小滝ほか (2002), 大阪湾北部は吉川ほか (1993), 琵琶湖湖底は吉川・井内 (1991) による. 国土地理院発行 2 万 5 千分の 1 地形図「蒜山」および「泰久寺」を使用.

層中の 4 層のテフラについて，詳細な岩石記載的特徵を 明らかにする.ささに, DOPが大山最下部テフラ層の hpm1 軽石 (hpm1 : 岡田ほか, 1990) に対比される可能 性，ならびに DBP が広域に分布する可能性を考察する.

\section{II. 分析地点におけるテフラ層序}

大山火山東麓に堆積する 20 層以上のテフラの層序を, 佐治ほ汃 (1975), 町田・新井 (1979, 2003), 津久井 (1984)，三浦・林 (1991)，岡田・石賀 (2000) に基づき, 表 1 に示した. 以下では, テフラ名とその略号を岡田・ 石賀 (2000) に基づて記載する.

岡山県八束村蒜山原下福田の露頭 (Loc. 1, 困 1, 困 2) は, 蒜山原で DOP の全層準が露出する地点であり, DOPの上位には hpm 2, DBP, DHP, Nh, AT, Sh, Od, Uh, MsPの 9 層のテフラが堆積している. DOP と DBP は，層相からそれぞれ 4 層と 2 層の堆積ユニットに区分 される. Loc. 1 では, DOPから 6 試料, hpm2 から 1 試 料, DBP と DHP から各 3 試料, $\mathrm{AT}$ 加ら 2 試料, $\mathrm{Sh} \sim$
MsP から各 1 試料の合わせて 19 試料 (試料 S1 S19, 図 2)を採取した。

鳥取県倉吉市大势河志の露頭 (Loc. 2, 図 1，図 2) では， 現在かつて見られた DNP から上位のテフラや最下位の apm は観察できない.このため, bvs1から hpm2まで のテフラを記載し，合わせて 20 試料を採取した（試料 O1〜O20, 図 2). Loc. 1 との比較のため, hpm1 につい ては 3 層準に分けて試料を採取した（試料 O $2 \sim 04$, 図 2).

\section{III. 分 析 方 法}

採取したテフラ試料のうち, Loc. 1 の全試料 (試料 S1 〜S19) と Loc. 2 の 4 試料（試料 O1〜O4）を分析した. 試料を自然乾燥後，超音波洗浄し，水流中で篩い分けて シルト以下の粒子を除去した，得られた粒径 $1 / 16 \mathrm{~mm}$ 以上の粒子を $60^{\circ} \mathrm{C}$ で 8 12 時間乾燥後, 粒径 $>1 / 2 \mathrm{~mm}$, 1/2〜1/4 mm, 1/4〜1/8 mm, 1/8〜1/16 mm の 4つの集 団に篩い分け，粒径 $1 / 8 \sim 1 / 16 \mathrm{~mm}$ の粒子について，以 
表 1 大山テフラ層の層序区分とその対比

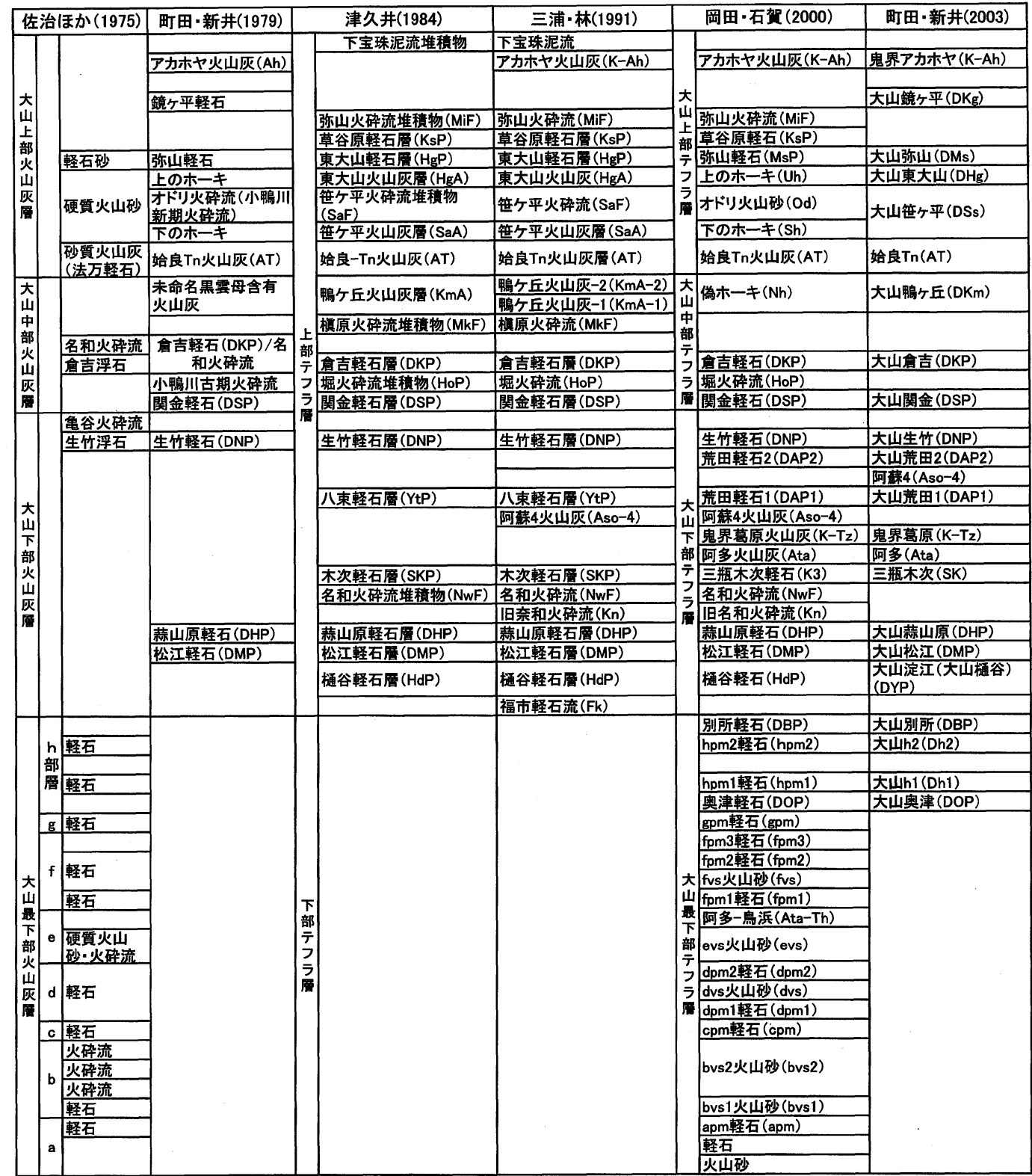

* 弥山軽石 (町田·新井, 1979) とDMs (町田・新井, 2003)は, $\mathrm{HgP}$ (津久井, 1984; 三浦・林, 1991) とMsP(岡田・石賀, 2000)に相当する. *Aso-4の首位を, 三浦·林(1991) や岡田·石賀 (2000) はYtPやDAP1の直下, 一方, 町田・新井(2003) はDAP1〜DAP2間としている.

* HdP(津久井, 1984) は淀谷軽石 (DYP:荒川, 1984)に相当する. HdPやDMPと, DBPを含めて下位のテフラとの層位関係は明らかになっていない,

*大山火山起源のテフラの他,これまでに明らかにされた広域テフラとその層準を示した

下の岩石記載的特徵を分析した.

1. 粒子組成・重鉱物組成・火山ガラスの形状組成・ 斜方輝石の形状

粒径 1/8 1/16 mm の粒子をカナダバルサムでスライ
ドグラス上に固定し，カバーグラスをかけてプレパラー 卜を作成した．これを偏光顕微鏡下で観察し，ランダム に粒子 200 個を同定して粒子組成を，重鉱物 200 個を同 定して重鉱物組成 A を，火山ガラス 200 個を同定して 
火山ガラスの形状組成をそれぞれ算出した. 粒子組成 は, 火山ガラス (Gl), 岩片 (Rf), 軽鉱物 (Lm), 重鉱物 (Hm), その他 (Ot)の 5 種類に区分した. 重鉱物は斜方 輝石 (Opx), 単斜輝石 (Cpx), 緑色普通角閃石 (Gho), 褐色普通角閃石 (Bho), カミングトン閃石 (Cum), 不透明 (鉄) 鉱物 $(\mathrm{Opq})$, 黒雲母 $(\mathrm{Bt})$, ジルコン $(\mathrm{Zr})$,
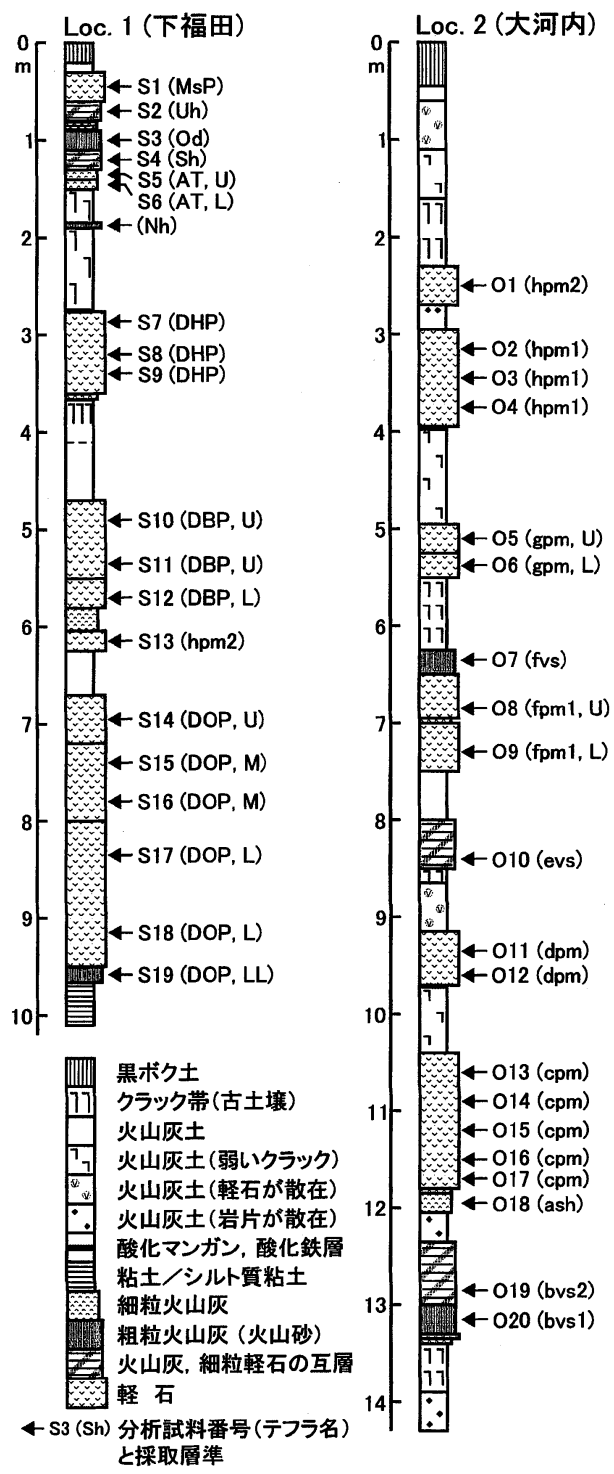

図 2 テフラ露頭の地質柱状図

露頭の位置は図 1 に示す. テフラ名の略号は表 1 を参照. 肉眼で識別された降下ユニットは, 略号に続き下位より LL, L, M, U の記号を付して示した.
燐灰石 $(\mathrm{Ap})$ の 9 種類を同定した. カミングトン閃石や 褐色普通角閃石は，粒径 $1 / 8 \mathrm{~mm}$ 以上の粒子についても その有無を確認した. 火山ガラスの形状は吉川（1976）に 準じ，扁平 $(\mathrm{H})$ 型，中間 (C) 型，多孔質 (T) 型，その 他 $(\mathrm{O})$ の 4 種類に分類し，それぞれの割合を算出した.

火山ガラスがほとんど含まれない DOP, hpm1, hpm2, DBP, DHP の 5 層のテフラについては, 粒径 $1 / 8 \sim 1 / 16$ $\mathrm{mm}$ の粒子 $1 \sim 2 \mathrm{~g}$ を比重 2.70 に調整した SPT 重液を 用いて分離した．重液分離した 2 つの粒子集団を超音波 洗浄し, $60^{\circ} \mathrm{C}$ で 8 12 時間乾燥した後, それぞれの重量 を計り, 比重 2.70 未満の粒子を「軽鉱物 + そ他」, 比 重 2.70 以上の粒子を「重鉱物」とし，それらの重量比を 求めた．また上と同様に,「重鉱物」粒子のプレパラート を作成し，偏光顕微鏡下でランダムに 500 個を同定して 重鉱物組成 Bを算出した. SPT 重液の粘性が高いため, 黒雲母のような板状の鉱物は浮いてしまう.このため, 重液分離した「重鉱物」中には，黒雲母がほとんど含ま れず，それを多く含むテフラでは重鉱物組成 A と重鉱 物組成 B とは一致しない(表 2，表 3).

さらに，斜方輝石が相対的に多く含まれる Loc. 1 の 試料について, 偏光顕微鏡下でランダムに選んだ斜方輝 石 50 個以上を破片状 ( $\mathrm{F}$ ：溶食により原形をほ上んよ゙ 失った斜方輝石を含む) 之柱状 (C) に分類・計数し, 両 者の個数比 $(\mathrm{F} / \mathrm{C})$ を算出した. また，柱状結晶 50 個以 上について, 結晶の伸長方向の最大長 $(\mathrm{L})$ と, それに直 交する方向の最大長 (I) の比 L/I を接眼レンズの目盛り を利用して求め, その平均值 (以下では (L/I) と記す)を 算出した.

\section{2. 火山ガラスと重鉱物の屈折率}

火山ガラスと重鉱物の屈折率は, 温度変化型屈折率測 定装置 (RIMS86 むしくはRIMS2000) を用いて測定し た. 火山ガラスの屈折率 (n) は, 檀原 (1993) に従ってガ ラス片 30 個以上を測定した. 斜方輝石・普通角閃石・ カミングトン閃石の屈折率は, 鎌田ほか (1994) に従っ て結晶片 30 個以上を測定した. ただし, 含有量が極微量 の重鉱物には測定個数が 30 個未満の試料あある.

\section{IV. テフラの岩石記載的特徵}

分析した 9 層のテフラの岩石記載的特徵を述べる. 以 下では, 特にことわりのない限り, テフラの重鉱物組成 は重鉣物組成 $\mathrm{A}$ に基づいて記載する.

1. 大山最下部・下部テフラ層のテフラ

DOP (Loc. 1 の試料 S19 S14)：DOP は S16 を除き, 個数比・重量比之あ軽鉱物が重鉱物よりあ多い（表 2, 


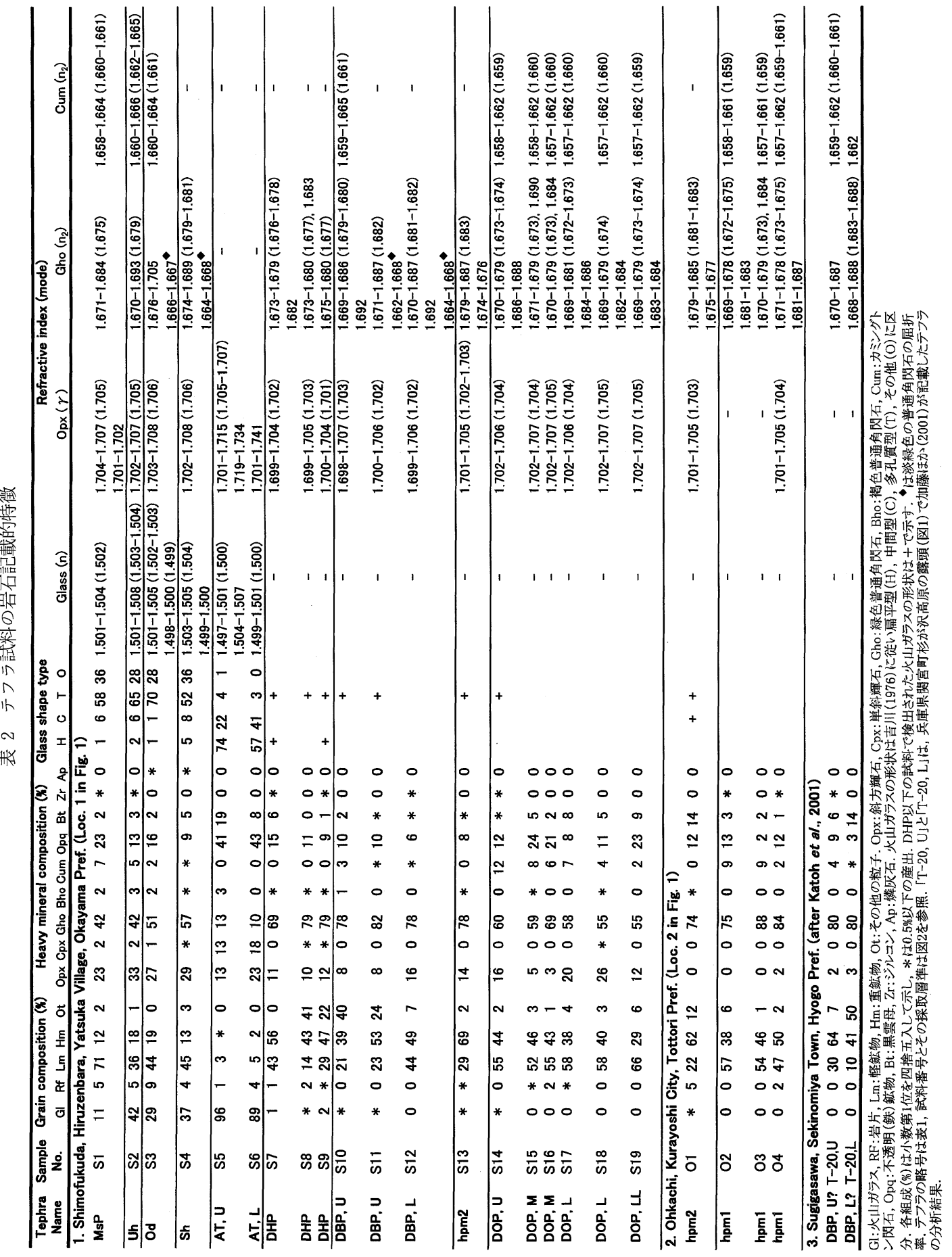


表 3 重液分離した大山テフラの試料の岩石記載的特徵

\begin{tabular}{|c|c|c|c|c|c|c|c|c|c|c|c|c|c|c|}
\hline \multirow{2}{*}{$\begin{array}{l}\text { Tephra } \\
\text { Name }\end{array}$} & \multirow{2}{*}{$\begin{array}{c}\text { Sample } \\
\text { No. }\end{array}$} & \multirow{2}{*}{$\begin{array}{c}\mathrm{Hm} / \\
(\mathrm{Lm}+\mathrm{Ot})\end{array}$} & \multicolumn{8}{|c|}{ Heavy mineral composition (\%) } & \multicolumn{4}{|c|}{ Shape index of Opx } \\
\hline & & & Opx & Cpx & Gho & Bho & Cum & Opq & & $\mathrm{Zr}$ & Ap & $\mathrm{F} / \mathrm{C}$ & $(L / I)$ & $S$ \\
\hline \multicolumn{15}{|c|}{ 1. Shimofukuda, Hiruzenbara, Yatsuka Village, Okayama Pref. (Loc. 1 in Fig. 1) } \\
\hline DHP & S7 & 1.15 & 14 & 0 & 79 & $*$ & $*$ & 7 & $*$ & 0 & 0 & 0.4 & 2.9 & 1.4 \\
\hline DHP & S8 & 0.79 & 11 & 0 & 79 & $*$ & 0 & 10 & 0 & 0 & 0 & 0.7 & 2.8 & 1.4 \\
\hline DHP & S9 & 1.41 & 10 & 0 & 83 & 1 & $*$ & 6 & $*$ & $*$ & 0 & 0.9 & 2.6 & 1.2 \\
\hline DBP,U & $\mathrm{S} 10$ & 0.96 & 7 & 0 & 81 & 1 & 2 & 9 & $*$ & $*$ & $*$ & 1.3 & 2.9 & 1.1 \\
\hline DBP,U & S11 & 1.28 & 4 & $*$ & 84 & $*$ & $*$ & 11 & $*$ & 0 & 0 & 1.8 & 2.7 & 1.1 \\
\hline DBP,L & $\mathrm{S} 12$ & 1.04 & 16 & $*$ & 74 & 0 & 0 & 9 & 0 & 0 & 0 & 0.6 & 3.0 & 1.7 \\
\hline hpm2 & $\mathrm{S} 13$ & 2.10 & 12 & 0 & 80 & 0 & 0 & 7 & 1 & 0 & 0 & 0.3 & 2.5 & 1.0 \\
\hline DOP,U & S14 & 0.77 & 13 & 0 & 67 & 0 & 8 & 11 & $*$ & $*$ & 0 & 0.3 & 2.5 & 1.0 \\
\hline DOP,M & S15 & 0.99 & $*$ & 0 & 66 & 0 & 10 & 23 & $*$ & 0 & 0 & - & - & - \\
\hline DOP,M & S16 & 1.11 & $*$ & 0 & 65 & 0 & 9 & 26 & 0 & 0 & 0 & - & - & - \\
\hline DOP,L & S17 & 0.94 & 20 & 0 & 65 & 0 & 5 & 10 & $*$ & 0 & 0 & 0.5 & 2.6 & 1.2 \\
\hline $\mathrm{DOP}, \mathrm{L}$ & S18 & 0.75 & 18 & 0 & 68 & 0 & 3 & 11 & $*$ & $*$ & 0 & 0.4 & 2.4 & 1.0 \\
\hline DOP,LL & $\mathbf{S 1 9}$ & 0.48 & 12 & $*$ & 69 & 0 & 2 & 16 & 1 & $*$ & 0 & 0.5 & 2.2 & 0.8 \\
\hline \multicolumn{15}{|c|}{ 2. Ohkachi, Kurayoshi City, Tottori Pref. (Loc. 2 in Fig. 1) } \\
\hline hpm2 & 01 & 1.57 & 3 & 0 & 85 & 0 & $*$ & 12 & $*$ & $*$ & 0 & - & - & - \\
\hline hpm1 & 02 & 0.80 & $*$ & 0 & 69 & 0 & 21 & 9 & 0 & $*$ & 0 & - & - & - \\
\hline hpm1 & O3 & 0.86 & $*$ & 0 & 71 & 0 & 20 & 8 & $*$ & $*$ & 0 & - & - & - \\
\hline hpm1 & 04 & 1.45 & 2 & 0 & 85 & 0 & 5 & 9 & 0 & $*$ & 0 & - & - & - \\
\hline
\end{tabular}

テフラの略号, 試料番号とその採取層準, 粒子組成と重鉱物組成の略号は, それぞれ表 1 , 図 2 , 表 2 を参照. 重鉱物組成 (\%) は小数第 1 位を四捨五入して示した。 ${ }^{*}$ は $0.5 \%$ 以 下の産出. 斜方輝石の形状指数の $\mathrm{F} / \mathrm{C}$ は破片状 (F) 之柱状 (C) の結晶の個数比, (L/I) は結晶の伸長方向の最大長 (L) とそ㣗に直交する方向の最大長 (I) の比 (L/I) の平均値, $\mathrm{S}$ は (L/I) の標準偏差であり, ともに小数第 2 位を四捨五入して示した.

表 3). 重鉱物組成は, 緑色普通角閃石が主で, 斜方輝石 とカミングトン閃石を伴い, 少量の黒雲母と極微量のジ ルコンを含む (表 2). 斜方輝石は, 最下部 (LL), 下部 (L)，上部 (U) の 3 つのユニットで $12 \%$ 以上を占める が，中部 (M) ユニットでは $5 \%$ 以下である. カミングト ン閃石は, 最下部ユニットと下部ユニットの下部で 2 4\%であるが，それより上方に向け含有量を増し，下部 ユニットの上部から上部ユニットで $6 \sim 12 \%$ 含まれる.

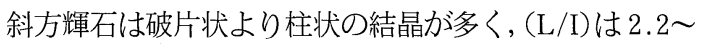
2.6 と小さく, 最下部ユニットで 2.2 と最小值を示し, 下部・上部ユニットで増大する (表 3, 図 3). 屈折率は, 斜方輝石が $\gamma=1.702-1.707$ (モードは 1.704-1.705, 以下 同じ), カミングトン閃石が $\mathrm{n}_{2}=1.657-1.662$ (1.6591.660) で, ともによく集中する (表 2 , 図 4). 緑色普通 角閃石は, 屈折率 $\mathrm{n}_{2}=1.669-1.678$ (1.672-1.674) の結 晶が大半で, $\mathrm{n}_{2}=1.680-1.690$ のより高屈折率の結晶が 微量含まれる (表 2, 図 4).

hpm1 (Loc. 2 の試料 04 02)：hpm1 は O4 を除き, 個数比・重量比亡も軽鉱物が重鉱物よりも多い(表 2, 表 3). 重鉱物組成は, 緑色普通角閃石が多く, カミング トン閃石之不透明 (鉄) 鉱物を伴い, 少量の黒雲母, 微量 の斜方輝石, 極微量のジルコンを含む (表 2). 斜方輝石 は下部にやや多く, 中部・上部にはほとんど含まれな い. 斜方輝石は, 先端部がささくれだった形状の結晶が
大半である. カミングトン閃石は下部では $2 \%$ である が, 中部・上部で $9 \%$ 含まれる. 屈折率は, 斜方輝石が 下部で $\gamma=1.701-1.705$ (1.704), カミングトン閃石が $\mathrm{n}_{2}=1.657-1.662$ (1.659-1.661) で，とすによく集中する （表 2, 図 4). 屈折率 $\mathrm{n}_{2}=1.669-1.679$ (1.672-1.675)の 緑色普通角閃石が大半であるが， $\mathrm{n}_{2}=1.681-1.687$ のよ り高屈折率の結晶が微量含まれる(表 2 , 図 4).

hpm2 (Loc. 1 の試料 S13， Loc. 2 の試料 01) : hpm2 はLocs. 1，2 の両地点に分布する (岡田, 1996). 両地点 における分析試料の岩石記載的特徵は, Loc. 2 の試料 O1で斜方輝石がほとんど検出されない点を除くと,よ く一致する (表 2, 表 3). hpm2 では, 個数比・重量比之 あに重鉱物が軽鉱物より著しく多い(表 2, 表 3)。重鉱 物組成は緑色普通角閃石を主とし, 不透明(鉄)鉱物・黒 雲母を伴うが，カミングトン閃石は含まれない(表 2). Loc. 1 の試料 S13 では, $14 \%$ の斜方輝石が含まれる. 斜方輝石は破片状より柱状の結晶が多く, (L/I) は 2.5 である (表 3, 図 3). いずれの地点でも, 斜方輝石の屈折 率は $\gamma=1.701-1.705$ (1.702-1.703) である. 緑色普通角 閃石の大半か淈折率 $\mathrm{n}_{2}=1.679-1.687$ (1.681-1.683) 示し, $\mathrm{n}_{2}=1.674-1.677$ の低屈折率の結晶を極微量含む (表 2, 図 4).

DBP (Loc. 1 の試料 S12 S10)：DBP は個数比- 重 量比ともに重鉱物が軽鉱物よりも多いか, 同程度である 


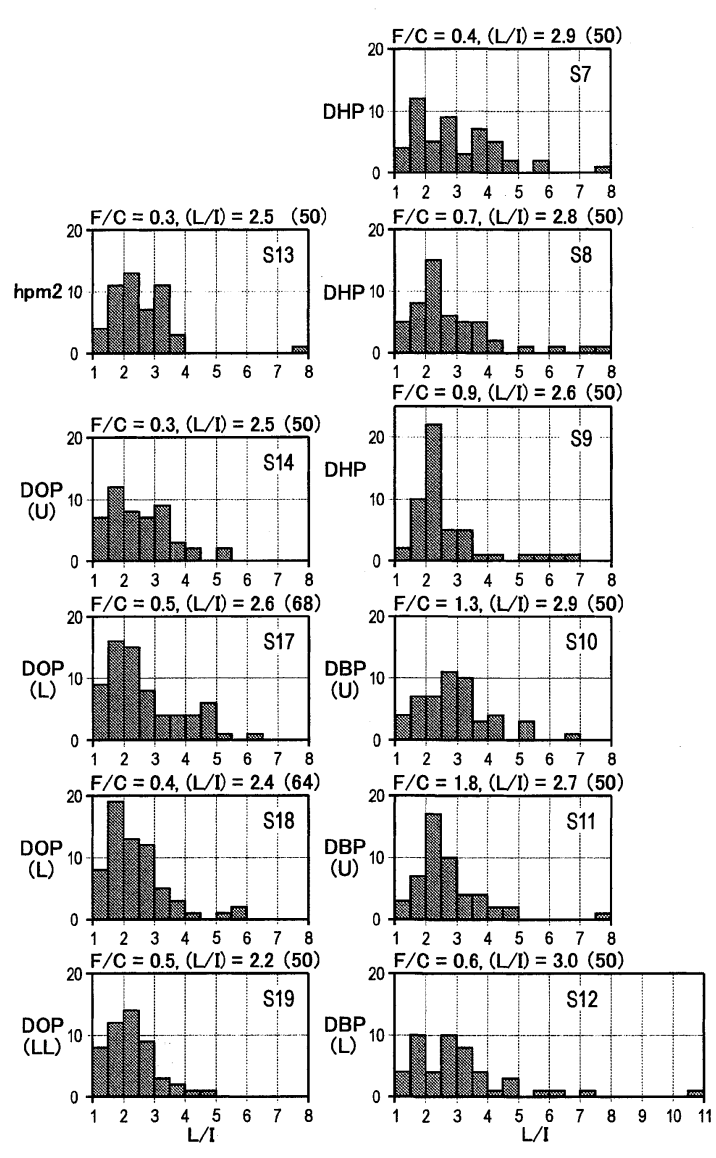

図 3 DOP, DBP, hpm2, DHP のテフラ試料に含まれる 斜方輝石の $\mathrm{L} / \mathrm{I}$ の頻度分布

(L/I) は, 結晶の伸長方向の最大長 $(\mathrm{L})$ とそれに直交す る方向の最大長 (I) の比 (L/I) の平均值を示す. F/C は 破片状 (F) 己柱状 (C) の結晶の個数比.

(表 2, 表 3). 上部 (U) ユニットは風化鉱物 (ゲーサイト など)に富む．重鉱物組成は, 緑色普通角閃石が多く, 斜 方輝石亡不透明 (鉄) 鉱物を伴い, 少量の黒雲母と極微 量のジルコンを含む (表 2). カミングトン閃石と褐色普 通角閃石は, 重鉱物組成 $\mathrm{A}, \mathrm{B}$ とも, 下部 (L) ユニット および上部ユニットの下部ではほとんど含まれない(表 2, 表 3). これらでは, 濃緑色の普通角閃石亡淡緑色の普 通角閃石の双晶, ないしは後者が前者に包有されるもの が極微量認められる. 上部ユニットの上部では, カミン グトン閃石 (3\%) と褐色普通角閃石 (1\%) が微量含まれ る (表 2). 斜方輝石は下部ユニットに多く含まれ, (L/I) は2.7〜3.0であり, 上部ユニットでは破片状の結晶

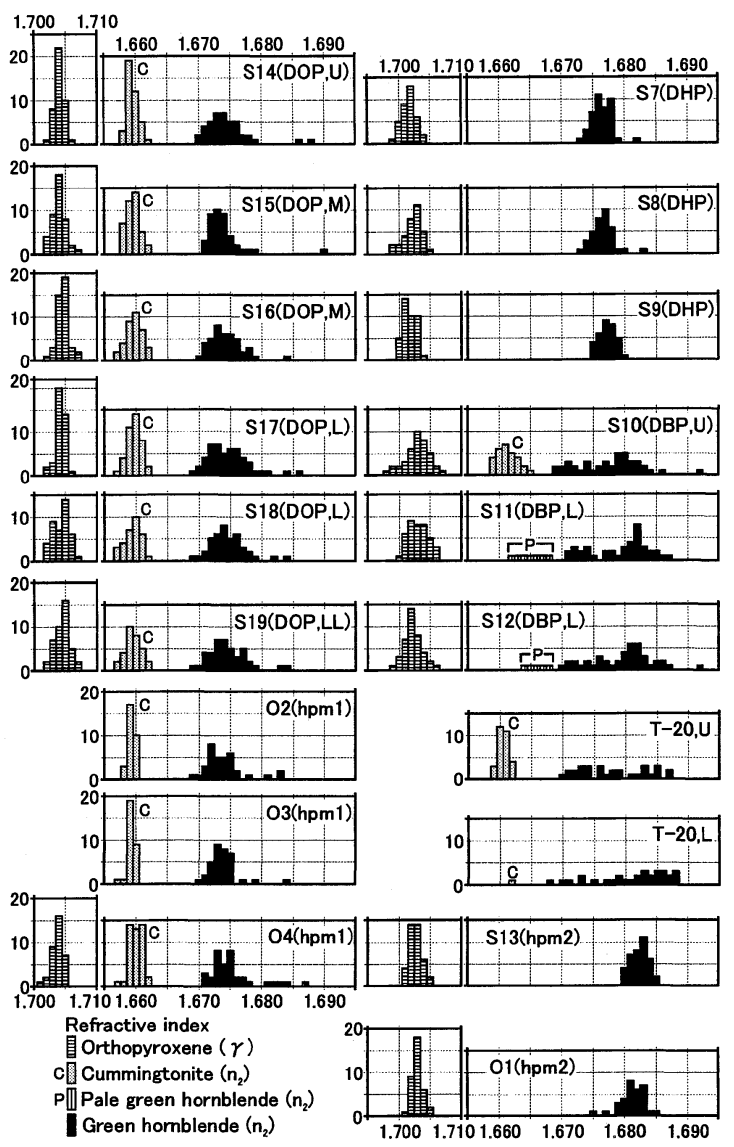

図 4 大山最下部・下部テフラ層のテフラ試料における 斜方輝石, 普通角閃石, カミングトン閃石の屈折 率の頻度分布

DOP, hpm1, hpm2, DBP, DHP について示す. 試料採取層 準は図 2 参照.「T-20, U」, 「T-20, L」は兵庫県関宮町杉ヶ沢 高原の露頭 (図 1) で加藤ほか (2001) が記載したテフラ.

が多い（表 3, 図 3). 斜方輝石の屈折率はDOP, hpm 1, hpm2 よりも若干低く, $\gamma=1.698-1.707$ (1.702-1.703) の範囲でややばらつく（表 2 , 図 4). カミングトン閃石 の屈折率は, 上部ユニットの上部で $\mathrm{n}_{2}=1.659-1.665$ (1.661)であり, DOP やhpm1 のそれより高い方に偏し ている(図 4). 緑色普通角閃石の屈折率は, $\mathrm{n}_{2}=1.669-$ 1.687 (1.679-1.682) の範囲で大きくばらつき, $\mathrm{n}_{2}>$ 1.690 の高屈折率の結晶が極微量含まれる (図 4). 淡緑 色の普通角閃石は, $\mathrm{n}_{2}=1.662-1.668$ の低屈折率を示す.

DHP (Loc. 1 の試料 S9～S7)：DHP は個数比・重量 比ともに重鉱物が多く, 中・下部は風化鉱物 (ゲーサイ トなど) に著しく富む (表 2, 表 3). 多孔質型火山ガラ 
ス ややガラスの付着した斜長石が極微量認められた．重 鉱物組成は, 多量の緑色普通角閃石之少量の斜方輝石 · 不透明 (鉄) 鉱物加引なり, 微量〜少量の黒雲母を含む （表 2). 重鉱物組成 A では淡緑色と褐色の普通角閃石 が，重鉱物組成 Bではそれらに加えてカミングトン閃石 が, 極微量検出された (表 2, 表 3). 斜方輝石は柱状の結 晶が破片状よりも多く，(L/I) は2.6〜2.9である（表 3, 図 3). 屈折率は, 斜方輝石で $\gamma=1.699-1.705$ (1.7011.703), 緑色普通角閃石で $\mathrm{n}_{2}=1.673-1.683$ （1.6761.678)である(表 2 , 図 4).

\section{2. 大山上部テフラ層のテフラ}

AT (Loc. 1 の試料 S6, S5)：AT の岩石記載的特徵 は, 両輝石型の重鉱物組成や屈折率 $\mathrm{n}=1.499-1.501$ の 火山ガラス (扁平型 >中間型) が粒子の大半を占めるこ と, $\gamma>1.730$ の高屈折率の斜方輝石を伴うなどの点 (表 2, 図 5) で, 町田・新井 (1976) の記載之一致する. しか し, 不透明 (鉄) 鉱物, 黒雲母, 緑色普通角閃石力相対的 に多く(表 2), さらに上部 (U) ユニットでは $\mathrm{n}=1.505$ 前後の多孔質型ガラスや, $\gamma=1.700-1.710$ の低屈折率の 斜方輝石力増加する (表 2, 図 5).

Sh, Od, Uh, MsP (Loc. 1 の試料 S4 S1)：Sh, Od, Uh は類似した岩石記載的特徴を示す (表 2). 粒子組成は, 30 ５0\%を占める火山ガラスと軽鉱物，10２0\%の重 鉱物，10\%未満の岩片からなる. 重鉱物組成は，緑色普 通角閃石が多く, 斜方輝石之不透明 (鉄) 鉱物を伴い, 少 量の黒雲母之極微量の単斜輝石・燐灰石を含む. 褐色普 通角閃石とカミングトン閃石は Od と Uh に $2 \sim 5 \%$ 含 まれ (表 2), Sh と Od は淡緑色の普通角閃石を極微量 含む．最上位の MsP は軽鉱物が著しく多く，10\%前後 の火山ガラス・重鋐物之 $5 \%$ 以下の岩片を伴う．重鉱物 組成は下位の Sh, Od, Uh に類似するが，より多くの不 透明 (鉄) 鉱物とカミングトン閃石を含む (表 2). 火山ガ ラスの形状は，いずれのテフラあよく似ており，多孔質 型とその他のガラスからなる. 火山ガラスの屈折率は, Sh で $\mathrm{n}=1.503-1.505$ (1.504), Od で $\mathrm{n}=1.501-1.505$ (1.502-1.503), Uh でn=1.501-1.508 (1.503-1.504), $\mathrm{MsP}$ では $\mathrm{n}=1.501-1.504$ (1.502) であり，MsPのガラ スの屈折率は下位のテフラのそれより低い(表 2, 図 5). 斜方輝石の屈折率にはほとんど差がなく，4 層とも $\gamma=$ 1.701-1.708 (1.705-1.706) を示す (表 2, 図 5). 緑色普 通角閃石の屈折率は Odが最む高く，ばらつきも大きい $\left(\mathrm{n}_{2}=1.676-1.705\right) . S h$ は $\mathrm{n}_{2}=1.674-1.689$ (1.679-
1.681)を, Uh は $\mathrm{n}_{2}=1.670-1.693(1.679)$ を, MsP は $\mathrm{n}_{2}=1.671-1.684$ (1.675)を，それぞれ示す．カミングト ン閃石の屈折率は, Od が $\mathrm{n}_{2}=1.660-1.664$ (1.661), Uh が $\mathrm{n}_{2}=1.660-1.666$ (1.662-1.665), $\mathrm{MsP}$ が $\mathrm{n}_{2}=1.658$ 1.664 (1.660-1.661) である. Sh と Odに極微量含まれ る淡緑色の普通角閃石は, $\mathrm{n}_{2}=1.664-1.668$ の低屈折率 を示す(表 2, 図 5).

\section{V. 考 察}

\section{DOP と hpm1 の対比の可能性}

DOP, hpm 1,hpm 2, DBP, DHPの中で, 下福田 (Loc. 1) と大河内 (Loc. 2) における hpm2 の岩石記載 的特徵はよく一致し, この対比は確実であると判断でき る. DOP と hpm1 は, $45 \mathrm{~cm}$ と $25 \mathrm{~cm}$ の厚さの火山灰土 層を挾んで，いずれす hpm2 の下位にある．これらで は, 軽鉱物が重鉱物よりあ多い点, カミングトン閃石や 斜方輝石の含有量の垂直変化，斜方輝石・緑色普通角閃

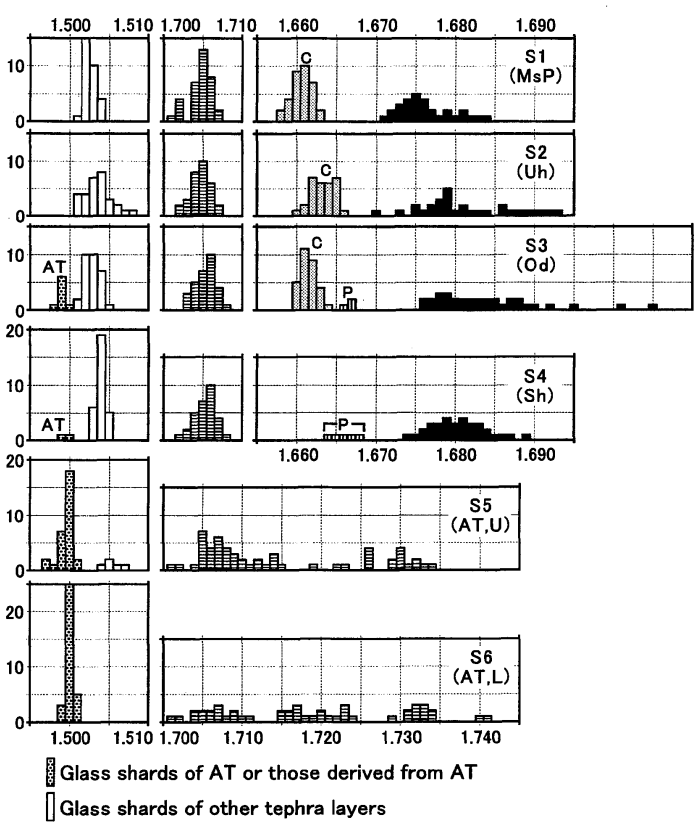

図 5 AT とその上位の大山テフラ試料の火山ガラス, 斜 方輝石, 普通角閃石, カミングトン閃石の屈折率の 頻度分布

試料 S3〜S5 では, 火山ガラスの形態と屈折率から AT 起源と大山テフラ起源の火山ガラスを区別した。試料採 取層準は図 2 を, ヒストグラムの凡例は図 4 を参照.

1）DHP 起源の火山ガラスであるとは断定できないが, 多孔質型ガラスの屈折率は, 試料 S9 で $\mathrm{n}=1.507-1.512$ (9片), $\mathrm{S} 7$ で $\mathrm{n}=1.507-1.510$ (5片) である. 
石・カミングトン閃石の屈折率がともによく一致する （表 2，図 4). 木村ほ汃 (1999）による之，DOP と hpm1 に含まれるジルコンのフィッション・トラック年代はそ れぞれ $190 \pm 60 \mathrm{ka}$ と $230 \pm 70 \mathrm{ka}$ であり, 誤差 $(1 \sigma)$ 範囲 内で一致する上，ジルコンのウラン濃度はともに 140 ppm である. 緑色普通角閃石やカミングトン閃石の主 成分組成 (小滝ほか, 2002) も, DOP と hpm1 ではよく 似る.このように DOP と hpm1 は，同一の層位にあっ て岩石記載的特徴や推定噴出年代など多くの特徵が一致 し，同一噴火によるテフラである可能性がある.

一方，岡田・石賀 (2000) は, Loc. 2 の約 $2 \mathrm{~km}$ 南方の 大山池畔露頭において, 重鉱物組成之強磁性鉱物の熱磁 化特性を指標に，上位から hpm2, hpm 1, BP $3^{2)}$, DOP を識別・記載した. DOP と hpm1の強磁性鉱物のキュ リ一点主相温度は $445 \sim 470^{\circ} \mathrm{C}$ の範囲にあって, 各テフ ラ層内では上方に向かって高くなる傾向を示し, 類似性 が高い (岡田ほか, 1990 ; 岡田, 1996). 副相温度は DOP で 130 150 ${ }^{\circ} \mathrm{C}$ (岡田, 1996), hpm 1 で $150 \sim 180^{\circ} \mathrm{C}$ であ り, 両テフラで差異があるとされだ) (岡田, 1998 ; 岡 田・石賀, 2000). しかし, 大山池畔露頭で DOP に対比 されたテフラは, カミングトン閃石の含有量が $3 \%$ 未満 でキュリー点副相温度は約 $110^{\circ} \mathrm{C}$ であり（岡田・石賀, 2000), 蒜山原で記載された DOP の特徴 (岡田, 1996) と は異なる. BP3についてあ，キュリ一点主相温度に10〜 $20^{\circ} \mathrm{C}$ 差がある.

したがって, 強磁性鉱物の熱磁化特性に基づく DOP と hpm1 の識別には, 問題力残されている. 今後, 両テ フラの強磁性鉱物についてキュリー点副相温度の地点間 のばらつきを定量的に評価し, 多くの露頭で各テフラの 緑色普通角閃石やカミングトン閃石の屈折率を測定し て, DOP と hpm 1 との対比む考慮に入れた両者の層序 関係を再検討する必要があろう.

\section{DBP の広域分布の可能性}

DBP はカミングトン閃石を含まない (岡田, 1996) と されていたが，上部には $3 \%$ 程度のカミングトン閃石が 含まれる (表 2).これに加えて, 緑色普通角閃石の屈折 率が広範囲でばらつくことや, カミングトン閃石の屈折 率 $\left(\mathrm{n}_{2}=1.659-1.665\right.$; モードは 1.661) が DOP のそれ よりやや高いこと（表 2, 図 4) は, 遠隔地における DOP と DBP の識別に有効である.

2) 岡田・石賀 (2000) は, 岡山県中和村別所の露頭で, DHP の下位に堆積する 9 層の軽石層を上位から BP1〜BP9 と呼び, このうち BP1, BP2, BP4 をそれぞれ DBP, hpm2, DOP に対比している.

3）岡田 (1998) が記載した鳥取県大栄町西高尾の西高尾ダム露頭における hpm1 の強磁性鉱物のキュリ一点副相温度は, 同論文の表 1 で $174^{\circ} \mathrm{C}$ と記載されている。 しかし，同論文の図 4 では標準試料ととあに $140^{\circ} \mathrm{C}$ 前後にあることが示され ており，これはDOP の強磁性鉱物のキュリー点副相温度と一致している.
加藤ほか (2001) は, 兵庫県北部の鉢伏山周辺 (図 1) でhpm2ないし DOP に対比できる含カミングトン閃石 テフラを記載したが，対比されたテフラ（試料 T-20）の 岩石記載的特徵は，本研究で明らかにした DOP や hpm 2 のそれ之一致しない．試料 T-20 は重鉱物が軽鉱物よ りも著しく多く(個数比), 下部 (T-20, L) でカミングト ン閃石をほとんど含まず，上部（T-20，U）で $4 \%$ の力ミ ングトン閃石を含み, 緑色普通角閃石の屈折率は $\mathrm{n}_{2}=$ 1.668-1.688 でばらつき，カミングトン閃石の屈折率は $\mathrm{n}_{2}=1.659-1.662$ (1.660-1.661) で，DOPのそれより若 干高い方に偏している（表 2, 図 4)。こうした特徴は DBP の岩石記載的特徽によりよく一致することから, 試料 T-20 は DBP に対比される可能性が高い. 試料 T20 は，大山火山加東へ約 $100 \mathrm{~km}$ 離れた兵庫県関宮町 杉が沢高原で採取され，厚さ $50 \mathrm{~cm}$ を示す (加藤ほか, 2001)ことから，DBPの分布域は少なくと屯近畿地方に 及ぶと推定される。

\section{DHP, Sh, Uh, MsP の対比に有効な岩石記載的特徵}

DHP は岡田（1996）が示したように, 粒径 1/8 1/16 $\mathrm{mm}$ の重鉱物中に $10 \sim 15 \%$ の斜方輝石を含んでいる （表 2，表 3). しかし，粒径 $1 / 8 \mathrm{~mm}$ 以上の粒子には町 田・新井 (1979) が記載したように，斜方輝石がほとん ど含まれていない. したがって，DHPには細粒の斜方輝 石が含まれていると判断され，重鉱物組成の比較の際に は対象粒径に注意する必要があると考えられる。また， DHP の緑色普通角閃石の屈折率は DOP〜DBP のそれ と異なり (表 2, 図 4), 対比の指標として有効である.

$\mathrm{AT}$ 上位の大山テフラでは, Sh と Uh がとくに類似し た岩石記載的特徴を示す.しかし，Sh はカミングトン閃 石や褐色普通角閃石を含まず，緑色普通角閃石の屈折率 範囲がより小さく，モードがやや大きい(表 2, 図 5). MsP はカミングトン閃石を $5 \%$ 以上含み, 火山ガラスや 緑色普通角閃石の屈折率のモードが 4 者中で最小であ る.さらに Uh と MsPでは, カミングトン閃石の屈折率 が明瞭に異なる (表 2, 図 5)。このように Sh〜MsP で は, カミングトン閃石や褐色普通角閃石の含有量亡, 火 山ガラス・緑色普通角閃石・カミングトン閃石の屈折率 に違いがあり，これらを指標としてより明確な対比がで きると考えられる. 
謝辞 熊本大学理学部の故松田高明教授には, 大山テ フラの模式露頭を案内いただき，その層序をご教示いた だいた，兵庫県立大学理学部の森永速男助教授には，温 度变化型屈折率測定装置 (RIMS 86) の使用に際し, 便宜 を図っていただいた．兵庫県立人と自然の博物館の松原 尚志博士と兵庫県立大学自然・環境科学研究所の古谷 裕助教授には，文献入手にご協力いただいた．本稿は査 読者のご指摘により改善された．以上の方々に心よりお 礼申し上げます。なお本研究には平成 $14 \cdot 15$ 年度文部 科学省科学研究費補助金 (課題番号 : 14380034, 代表者： 加藤茂弘)の一部を使用した.

\section{引用文 献}

荒川 宏（1984）大山火山北西部における火山麓扇状地 の形成. 地理学評論, 57, 831-855.

檀原 徹 (1993) 温度变化型屈折率測定法. 日本第四紀 学会編「第四紀試料分析法 $2:$ 研究対象別分析法」: 149-158, 東京大学出版会.

福間敏夫・藤田和夫（1986）福知山盆地の中部更新統.

第四紀研究，24，263-281.

古澤 明・梅田浩司（2002 a）新期大山テフラ DNP, DSP, DKP の岩石記載的特徵の再検討. 第四紀研究,

41, 123-129.

古澤 明・梅田浩司（2002 b）大山最下部および下部火 山灰にはさまれるテフラの岩石記載的特徵. 第四紀研 究, $41,413-420$.

鎌田浩毅 - 檀原 徹 - 山下 透 - 星住英夫 - 林田 明 竹村恵二 (1994) 大阪層群アズキ火山灰および上総層 群 Ku6C 火山灰と中部九州の今市火砕流堆積物との 対比一猪牟田カルデラから噴出した co-ignimbrite ash一. 地質学雑誌, $100,848-866$.

加藤茂弘 · 大森繁雄 - 松田高明 - 山下 透 - 檀原 徹 . 先山 徹 - 半田久美子 - 佐藤裕司 - 古谷 裕 - 小林文 夫（2001）兵庫県北西部・鉢伏山周辺地域の第四紀後 期テフラ層序一大山火山起源のテフラを中心とし て一. 人と自然, No. 12, 1-12.

木村純一 - 岡田昭明 - 中山勝博 - 梅田浩司 - 草野高志 . 麻原慶憲・館野満美子・檀原 徹 (1999) 大山および 三瓶火山起源テフラのフィッショントラック年代とそ の火山活動史における意義. 第四紀研究, 38, 145-155. 小滝篤夫 ·古山勝彦 ·井上陽一 (2002) 京都北部, 福知 山・綾部地域の高位段丘層中の含カミングトン閃石火 山灰層と大山最下部火山灰層之の対比. 地球科学, 56 ,
35-48.

町田 洋・新井房夫（1976）広域に分布する火山灰一姶 良 Tn 火山灰の発見とその意義. 科学，46，339-347. 町田 洋・新井房夫（1979）大山倉吉軽石層一分布の広 域性と第四紀編年上の意義. 地学雑誌，88，313-330. 町田 洋・新井房夫 (2003) 新編 火山灰アトラス〔日本 列島とその周辺了. $336 \mathrm{p}$, 東京大学出版会.

町田 洋・新井房夫・横山卓雄（1991）琵琶湖 $200 \mathrm{~m}$ コ アにおける指標テフラ層の再検討．第四紀研究， 30 , 439-442.

三浦 清・林 正久（1991）中国・四国地方の第四紀于 フラ研究一広域テフラを中心として一。第四紀研究, 30, 339-351.

岡田昭明（1996）大山蒜山原軽石（DHP）と大山最下部 火山灰 hpm 2 軽石について. 島根大学地球資源環境学 研究報告, 15, 53-60.

岡田昭明（1998）強磁性鉱物の熱磁気特性によるテフラ の同定. 鳥取大学教育学部研究報告 (自然科学), 47, 69-79.

岡田昭明・石賀 敏（2000）大山テフラ. 日本地質学会 第 107 年学術大会見学旅行案内書, 81-90.

岡田昭明・谷口 恵・木下直美（1990）模式地にお括る 大山最下部火山灰層中の強磁性鉱物の熱磁気特性. 鳥 取大学教育学部研究報告 (自然科学), 39, 143-160. 佐治孝式・田崎和江・赤木三郎・麻田 斉 (1975) 大山 火山降下堆積物の層序とその特徵. 地球科学, 29, 199210.

山陰第四紀研究グループ (1969) 山陰海岸地域の第四系. 地団研専報，15，354-376.

津久井雅志（1984）大山火山の地質．地質学雑誌，90, 643-658.

吉川周作（1976）大阪層群の火山灰について．地質学雑 誌, 82, 497-515.

吉川周作・井内美郎（1991）琵琶湖高島沖ボーリングコ アの火山灰層序．地球科学，45，81-100.

吉川周作・井内美郎（1993）琵琶湖高島沖ボーリングコ ア火山灰層序からみた中期更新世〜完新世の噴火活動 史. 地球科学, 47, 97-109.

吉川周作・那須孝悌・樽野博幸・古谷正和（1986）近畿 地方中部に分布する後期更新世〜完新世の火山灰層に つい. 地球科学, 40, 18-38.

吉川周作・小倉博之 ・福西佐代 (1993) 大阪平野地下の 中・上部更新統火山灰層序. 地質学雑誌，99, 467-478 


\title{
Correlation among the Tephra Layers in the Lowest Daisen Volcanic Ash Formation, Western Japan, on the Basis of Their Petrographic Properties
}

\author{
Shigehiro Katoh*1, Tohru Yamashita*2 and Tohru Danhara*2
}

We determined the detailed petrographic properties (grain composition, heavy mineral composition, morphology and refractive indexes of volcanic glass shards, and refractive indexes of orthopyroxene, hornblende and cummingtonite phenocrysts) for the following nine tephra layers of the Daisen Volcanic Ash Formation in the Chugoku District : the Daisen Okutsu Pumice (DOP), hpm1 Pumice (hpm1), hpm2 Pumice (hpm2), Daisen Beshyo Pumice (DBP), and Daisen Hiruzenbara Pumice (DHP) Beds of middle Pleistocene age, and the Shitano-hoki (Sh), Odori Volcanic Sand (Od), Uenohoki (Uh), and Misen Pumice (MsP) Beds immediately above the Aira-Tanzawa tephra. The tephra layers are distinguishable by ratios of heavy mineral crystals to light ones and con- tents of cummingtonite and brown hornblende phenocrysts, and by refractive indexes of glass shards, hornblende, and cummingtonite crystals in spite of their similarity of heavy mineral composition, morphology of glass shards, and refractive indexes of orthopyroxene phenocrysts. In these tephra layers, it is possible that DOP is correlated with hpm1, because they have very similar petrographic properties and occur at the same relative stratigraphic and chronostratigraphic horizon with fission-track ages. A 50-cm thick tephra layer found in the northern part of Hyogo Prefecture, about 100 $\mathrm{km}$ east of Daisen Volcano, is newly correlated with a DBP, indicating wide spread at least in the northern Kinki District.

*1 Museum of Nature and Human Activities, Hyogo. Yayoigaoka 6, Sanda, 669-1546, Japan. E-mail :

*2 Kyoto Fission-Track Co., Ltd. 44-4 Ohmiya Minamitajiri-cho Kita-ku, Kyoto, 603-8832, Japan. 